\title{
PERILAKU PASAR DAKWAH MUSLIM PERKOTAAN DALAM MENGIKUTI KAJIAN DAKWAH MAJELIS DZIKIR WALISONGO
}

\author{
Siti Nur Halimah \\ STID Al-Hadid, Surabaya \\ sitinurhalimah@stidalhadid.ac.id
}

\begin{abstract}
Abstrak: Dakwah serupa kegiatan pemasaran yang menawarkan nilai-nilai keagamaan kepada mad'uw dengan tujuan mad'uw menerima nilai Islam. Agar tercapai tujuan tersebut, pelaksana dakwah perlu memahami karakteristik respons mad'uw terhadap kegiatan dakwah sebagaimana pemasar memahami perilaku konsumen. Masyarakat muslim perkotaan merupakan mad'uw yang potensial. Masyarakat ini memiliki dinamika masalah hidup yang kompleks karena adanya perkembangan teknologi dan modernitas. Hal ini, menuntut strategi dakwah yang berbeda. Majelis Dzikir Walisongo merupakan salah satu majelis dakwah yang diminati oleh pasar dakwah muslim perkotaan. Indikatornya, pasar dakwahnya rela hadir pada kegiatan majelis yang diadakan jauh dari lingkungannya. Majelis ini diikuti oleh ratusan jemaah dari beragam profesi. Antusias jemaah mengajak orang terdekat ikut serta dalam pengajian, menjadikan majelis ini memiliki banyak pengikut melebihi umumnya jemaah pengajian di perkotaan. Sebagian jemaah memilih tetap menghadiri pengajian meskipun jadwalnya bentrok dengan pekerjaan. Tulisan ini, bermaksud mendeskripsikan perilaku pasar dakwah muslim perkotaan dalam mengikuti kajian Majelis Dzikir Walisongo. Metodologinya kualitatif dengan pendekatan fenomenologis. Pengumpulan data menggunakan wawancara dan observasi. Analisis data menggunakan pendekatan konsep masyarakat muslim perkotaan (urban muslim) dan teori perilaku konsumen. Hasilnya, jemaah terindikasi berperilaku sebagaimana praktik urban sufisme yang mementingkan aktifitas spiritual melalui pengajian dan zikir. Faktor yang mempengaruhi respons mereka terdiri dari beragam faktor internal dan eksternal. Kata kunci: Dakwah, Majelis Dzikir Walisongo, Perilaku Pasar, Muslim Perkotaan.
\end{abstract}

DA'WAH MARKET BEHAVIOUR OF URBAN MUSLIM IN FOLLOWING DA'WAH STUDY OF MAJELIS DZIKIR WALISONGO. Abstract: Da'wah resembles a marketing activity offering religious values to mad'uw (congregation). To achieve the goal, a da'wah executor needs to understand characteristics of congregation's responses towards the da'wah activity as a marketer understands consumer behaviour. Urban Muslim community is a potential congregation. It has complex life problems because of technology development and modernity. It demands different da'wah strategy. Majelis Dzikir Walisongo is one of da'wah sessions interested by da'wah market of urban Muslim. It can be seen from congregation's willingness to the session although conducted far from their residences. It is followed by hundreds of various professions. Their enthusiasm to ask other people around to participate makes the session attended by many followers more than usual urban congregations. Some even decide to keep attending the session although its schedule clashes with their work. This paper aims to describe market behaviour of urban Muslim in following Majelis Dzikir Walisongo. This qualitative research uses phenomenology approach. Its data are collected from interviews and observations and analysed by using approaches of urban Muslim community concept and consumer behaviour theory. It indicates the congregation practices urban Sufism prioritizing spiritual activities through Al Qur'an recitation and dhikr. Internal and external factors influence their responses.

Key words: Da'wah, Majelis Dzikir Walisongo, Market Behaviour, Urban Muslim 


\section{Pendahuluan}

Islam merupakan ajaran yang memiliki tatanan nilai, sudah semestinya ajaran tersebut disampaikan ke masyarakat agar tatanan nilai Islam terwujud dalam kehidupan bermasyarakat. Penyampaian nilai ajaran Islam dikenal dengan aktivitas dakwah. Dakwah mengupayakan agar sasaran atau mitra dakwah memahami nilai ajaran Islam dengan baik dan menerimanya sebagai cara hidup yang seharusnya diterapkan. Syarif menyampaikan bahwa, dakwah pada hakikatnya adalah upaya untuk menumbuhkan kecenderungan dan ketertarikan pada apa yang anda serukan, yakni Islam. ${ }^{1}$ Oleh karena itu, dakwah tidak hanya semata menyampaikan apa yang sudah tertulis dalam kitab suci Al-Qur'an dan hadis namun membuat mad'uw tergerak hati dan pikirannya untuk menerima nilainilai Islam sebagai kebenaran. Hal ini, karena dakwah dapat menjadi jalan bagi datangnya hidayah Allah kepada umat manusia untuk meyakini kebenaran Islam.

Fungsi dakwah dalam menyampaikan nilai ajaran Islam kepada mitra dakwah atau mad'uw hingga nilai tersebut diterima sejalan dengan fungsi pemasaran suatu produk. Pemasar suatu produk menawarkan produknya dengan metode dan cara tertentu agar pasar sasarannya tertarik mengonsumsi produk yang ditawarkan tersebut. Menurut Syarif, proses dakwah adalah sebuah proses marketing dengan produknya hal-hal yang didakwahkan, sebutlah Islam (sebagai produknya). ${ }^{2}$ Upaya mendakwahkan Islam sama halnya dengan

\footnotetext{
${ }^{1}$ Nasrul Syarif, "Marketing Dakwah," An-Nida" : Jurnal Prodi Komunikasi Penyiaran Islam 6, no. 1 (2017): 102, https://e-

jurnal.stail.ac.id/index.php/annida/article/view/73.

2 Ibid., 104.

3 Hendra Bagus Yulianto, “Manajemen Pemasaran
}

memasarkan nilai-nilai Islam kepada mitra dakwah, sehingga diperlukan metode dan cara yang tepat agar mencapai tujuannya.

Sebagaimana penerapan konsep dan strategi pemasaran, dakwah juga perlu menyesuaikan dengan karakteristik mad'uw $^{\prime}$ terkait respon mereka terhadap tawaran produk dakwah. Yulianto menyatakan, konsep dan strategi pemasaran direncanakan untuk memastikan agar produk yang dibuat itu dapat diterima oleh konsumen. Aspek "need and want" dari konsumen merupakan aspek fundamental dalam konsep pemasaran. Salah satu fungsi implementasi konsep pemasaran adalah upaya untuk menjamin suatu produk atau jasa yang akan dibuat dapat diterima oleh konsumen. ${ }^{3} \quad$ Berdasarkan pandangan tersebut, memahami perilaku konsumen memiliki kedudukan yang penting dalam pemasaran karena menjadi pijakan menyusun strategi pemasaran yang tepat. Pada bidang dakwah, seharusnya juga perlu memahami karakteristik mad'uw sebagai pijakan menetapkan strategi dakwah yang sesuai.

Keberhasilan suatu dakwah tidak hanya ditentukan oleh nilai pesan yang disampaikan, tetapi juga ditentukan oleh bagaimana persepsi mad'uw terhadap pesan dakwah itu. ${ }^{4}$ Artinya, respon mad'uw terhadap produk dakwah turut menentukan kesuksesan dari suatu penyelenggaraan dakwah. Lembaga dakwah perlu memahami lebih jauh terkait bagaimana pasar dalam merespon suatu produk dan apa saja faktor

\footnotetext{
Agama: Studi Tentang Strategi Dakwah Pengajian Bunda Muslimah Az-Zahra Sidoarjo" (UIN Sunan Ampe Surabaya, 2017), 4, http://digilib.uinsby.ac.id/19408/. 4 Ujang Muhadi, "Membangun Efektifitas Dakwah Dengan Memahami Psikologi Madu" 4, no. 1 (2019): 176, doi:10.29240/jdk.v4i2.1251.
} 
yang mempengaruhinya. Berbeda kondisi sosial, kondisi budaya dan kondisi politik maka berbeda pula cara dakwah, karena dakwah merupakan aktivitas yang sangat dinamis tidak bertahan untuk memaksakan dakwah pada satu metode saja. ${ }^{5}$ Berpijak pada pemahaman perilaku pasar dakwah yang tepat, Lembaga dakwah dapat menyusun pendekatan dan metode dakwah yang tepat serta dapat berdakwah dengan efektif dan efisien.

Pentingnya memahami karakteristik mad'uw dalam aktifitas berdakwah semakin tinggi ketika dihadapkan pada konteks dakwah di masyarakat muslim perkotaan atau yang disebut masyarakat urban. Adanya peningkatan penduduk kota yang cepat, penyebaran pendidikan umum non religius dan ilmu alam, peningkatan mobilitas dan akses informasi, industrialisasi, dan sebagainya telah mendatangkan tekanan bagi masyarakat perkotaan. ${ }^{6}$ Lingkungan hidup di wilayah perkotaan memberikan dinamika masalah pada masyarakatnya, sehingga mereka memiliki karakteristik kebutuhan berbeda menyesuaikan dinamika permasalahan yang mereka hadapi. Masyarakat urban sebagai konsumen bagi layanan dakwah, akan menilai baik buruknya layanan dakwah berdasarkan terpenuhinya kebutuhan mereka atau kesesuaian produk dakwah dengan karakteristik mereka. Oleh karena itu, lembaga dakwah perlu lebih banyak memahami karakteristik mad'uw nya

${ }^{5}$ Muhamad Irhamdi, “Keberagaman Mad'u Sebagai Objek Kajian Manajemen Dakwah: Analisa Dalam Menentukan Metode, Strategi, Dan Efek Dakwah," Jurnal MD 5, no. 1 (2019): 70 doi:https://doi.org/10.14421/jmd.2019.51-04.

${ }^{6}$ Muhammad Anis, "Spiritualitas Di Tengah Modernitas Perkotaan," Jurnal Bayan II, no. 4 (2013): 2 http://s3ppi.umy.ac.id/wp-

content/uploads/2017/04/Spiritualitas_di_Tengah_M yang merupakan masyarakat urban agar tujuan dakwah dapat tercapai.

Salah satu majelis dakwah yang hadir di tengah kehidupan masyarakat urban kota Surabaya adalah Majelis Dzikir Walisongo. Majelis Dzikir Walisongo merupakan majelis dakwah yang digagas oleh LDNU Surabaya. Majelis ini dibentuk pada April 2016 lalu, rutin mengadakan kegiatan kajian dua kali dalam satu bulan. ${ }^{7}$ Menurut keterangan pengurus, jemaah MDW (singkatan dari Majelis Dzikir Walisongo) berasal dari masyarakat kota Surabaya dan sekitarnya seperti Gresik dan Sidoarjo, sebagian merupakan kalangan jamiah NU yakni mereka yang berpaham ahlusunah waljamaah dan, sebagian lainnya masyarakat umum. ${ }^{8}$ Jemaah majelis ini, tercatat yang pernah menghadiri kajiannya berjumlah 200 orang pada setahun awal setelah diadakan. ${ }^{9}$ Angka yang cukup banyak untuk kategori jemaah majelis dakwah di masyarakat perkotaan, apalagi saat kegiatannya tergolong baru diselenggarakan. Awal kali pengadaan kajian dilaksanakan di rumah dakwah LDNU, jalan Pagesangan Asri, Surabaya, namun karena jemaah yang hadir bertambah banyak maka untuk memenuhi ketercukupan tempat pengajian, pengurus memindahkan tempat pelaksanaan kajian di masjid Ababil Surabaya. ${ }^{10}$

Lokasi kegiatan pengajian MDW ini tidak dekat dengan lingkungan rumah tinggal

odernitas_Perko.pdf

7 ER (Pengurus LDNU), Wawancara oleh Siti, tanggal 1 Februari 2017.

8 Ibid.

9 DW (Ketua Majelis Dzikir Walisongo), Wawancara Oleh Siti, 24 April 2017.

${ }^{10}$ ER (Pengurus LDNU), Wawancara oleh Siti, tanggal 1 Februari 2017. DW (Ketua Majelis Dzikir Walisongo), Wawancara oleh Siti, tanggal 24 April 2017. 
jemaah yang hadir. Masjid Ababil terletak di wilayah Surabaya Selatan, sedangkan jemaah datang dari berbagai penjuru meliputi wilayah Surabaya Utara, Surabaya Barat, bahkan ada yang dari luar kota seperti Gresik dan Sidoarjo. ${ }^{11}$ Kegiatan pengajian juga dilaksanakan pada hari minggu, sebagian jemaah ada yang berpofesi sebagai pedagang warung makan yang harus berjualan di hari minggu, karena umumnya banyak pelanggan datang untuk menikmati makanan di luar rumah (warung makan) justru pada hari libur, namun jemaah tersebut tetap memilih untuk menghadiri pengajian MDW dan membuka warung setelahnya. ${ }^{12}$ Salah satu jemaah ada yang berprofesi sebagai perias pengantin yang mengaku sering mendapatkan pesanan jasa rias pada hari minggu, namun masih berusaha menyempatkan waktu untuk hadir pada kegiatan pengajian dengan menata jadwal pekerjaannya menyesuaikan waktu pengajian MDW. ${ }^{13}$ Hal ini, seakan bertentangan dengan karakterisasi umum masyarakat muslim perkotaan yang selalu padat aktivitas, sehingga menginginkan kemudahan dalam mengonsumsi suatu produk misalnya, lebih memilih menyimak kajian dakwah melalui platform online atau memilih menghadiri majelis taklim yang waktunya sesuai dengan kesibukannya serta berlokasi dekat secara jarak dengan lingkungan tempat tinggalnya (berada dalam satu kampung atau perumahan yang sama).

Adanya fenomena jemaah dakwah MDW yang tergolong masyarakat urban, karena hidup di lingkungan perkotaan, namun dapat merespon produk dakwah dengan baik,

\footnotetext{
11 DW (Ketua Majelis Dzikir Walisongo), Wawancara oleh Siti, tanggal 24 April 2017.

12 WD (Jemaah Majelis Dzikir Walisongo), Wawancara oleh Siti, tanggal 5 Mei 2017.
}

merupakan aspek menarik yang ingin diulas dalam studi ini. Perilaku jemaah dalam merespon produk dakwah pada studi kasus jemaah MDW, dapat menjadi telaah baru studi perilaku konsumen dakwah masyarakat muslim perkotaan (urban) khususnya pada faktor-faktor yang mempengaruhi jemaah untuk menerima dengan baik tawaran produk dakwah MDW. Rumusan masalah dalam studi ini adalah deskripsi perilaku pasar dakwah dalam mengikuti Majelis Dzikir Walisongo. Tujuan studi untuk memahami karakteristik atau perilaku pasar dakwah dalam mengikuti Majelis Dzikir Walisongo. Kajian sejenis yang menjelaskan karakteristik masyarakat muslim kota banyak menggunakan pendekatan telaah konseptual maupun pendekatan sejarah, sedangkan studi ini memberikan sumbangsih analisis dari data faktual yang secara langsung diperoleh melalui wawancara jemaah. Pada tataran praksis, lembaga dakwah dapat menjadikan hasil studi ini, sebagai salah satu referensi memahami perilaku pasar dakwah masyarakat muslim kota.

Studi terdahulu yang dilakukan oleh Muhammad Anis, dalam jurnal ilmiah berjudul Spiritualitas di Tengah Modernitas Perkotaan ${ }^{14}$ menghasilkan temuan sebagai berikut: Pertama, spiritualitas dapat memiliki beragam bentuk tidak hanya dalam bentuk agama formal, melainkan dapat berupa kepercayaan nonformal, seperti semboyan Spiritual Yes, Religion No. Kedua, spiritualitas perkotaan atau dikenal dengan Urban Sufisme dianggap mulai banyak bergejala pada beberapa tahun terakhir saat

\footnotetext{
13 Ibid.

${ }^{14}$ Anis, "Spiritualitas Di Tengah Modernitas Perkotaan," 12-13.
} 
studi tersebut dilakukan. Ketiga, perkembangan spiritualitas ada yang mengarah ke bentuk fundamentalisme yang dalam banyak kasus sering menimbulkan persoalan psikologis misalnya menawarkan janji keselamatan absurd dan ketenangan batin yang bersifat sementara. Studi tersebut, memiliki perbedaan dengan tulisan ini pada aspek metode yang digunakan, yakni telaah konseptual dan pendekatan sejarah lahirnya spiritualitas di tengah perkembangan masyarakat modern, sedangkan studi ini menggunakan pendekatan fenomenologis dan spesifik pada studi kasus Majelis Dzikir Walisongo.

Adapun studi yang dilakukan Wasisto Raharjo Jati dalam jurnal ilmiah berjudul Sufisme Urban di Perkotaan: Konstruksi Keimanan Baru Kelas Menengah Muslim ${ }^{15}$, menghasilkan temuan terkait praktik dan pemaknaan sufisme urban dalam kasus menengah muslim Indonesia bersifat temporer dan reaksioner. Artinya, masyarakat kelas menengah muslim di Indonesia menerapkan peribadatan sufi saat mereka tertimpa masalah, dan meninggalkan sufi ketika masalah tersebut sudah dapat teratasi. Titik perbedaan dengan studi ini adalah fokus masalah dalam jurnal tersebut adalah praktik sufisme pada masyarakat kelas menengah perkotaan, namun tulisan ini berfokus pada karakteristik perilaku pasar dalam mengikuti majelis dakwah beserta faktor-faktor yang mempengaruhi respon tidak spesifik menjelaskan praktik perilaku sufisme mereka.

\footnotetext{
${ }^{15}$ Wasisto Raharjo Jati, "Sufisme Urban Di Perkotaan: Konstruksi Keimanan Baru Kelas Menengah Muslim," Jurnal Kajian \& Pengembangan Manajemen Dakwah 05, no. 2 (2015): 197.
}

Studi yang dilakukan oleh Bukhari dalam artikel jurnal berjudul Penerimaan dan Penolakan Pesan Dakwah Dalam Interaksi Simbolik Da'i dan Mad'u Pada Jamaah Tabligh di Kota Padang. ${ }^{16}$ Hasil studi, menjelaskan bahwa jemaah Majelis Tabligh kota Padang menerima pesan dakwah karena aspek ideologis dan keyakinan, pendekatan dakwah yang persuasif, bahasa yang menarik dan tidak memersoalkan khilafiyah. Sebagian jemaah yang menolak dakwah Jemaah Tabligh adalah karena menganggap cenderung fatalistis, tidak mementingkan duniawi dan adanya perilaku yang kurang simpatik terhadap pengurus Jemaah Tabligh. Persamaan dengan studi ini adalah aspek pendekatan yang digunakan yakni pendekatan fenomenologis, sedangkan perbedaannya pada aspek objek yang diamati yakni jemaah dakwah Majelis Tabligh di kota Padang dengan jemaah dakwah Majelis Dzikir Walisongo di kota Surabaya. Hal lainnya yang juga berbeda adalah teori yang digunakan, pada jurnal tersebut menggunakan teori etnometodologi sedangkan studi ini menggunakan teori perilaku konsumen khususnya pada faktor-faktor yang mempengaruhi respon atau perilaku konsumen.

Studi ini merupakan jenis studi deskriptif kualitatif dengan pendekatan fenomenologis. Metode pengumpulan data melalui wawancara dan observasi. Wawancara dilakukan kepada jemaah pengajian Majelis Dzikir Walisongo sebagai sumber data primer sejumlah sepuluh orang jemaah. Selain jemaah, terdapat sumber

\footnotetext{
${ }^{16}$ Bukhari, "Penerimaan Dan Penolakan Pesan Dakwah Dalam Interaksi Simbolik Da ' I Dan Mad ' U," Miqot 39, no. 2 (2015): 378, doi:http://dx.doi.org/10.30821/miqot.v39i2.31.
} 
data sekunder yakni pengurus Majelis Dzikir Walisongo, DW selaku ketua jemaah pengajian MDW dan ER selaku pengurus LDNU sekaligus penanggungjawab kegiatan Majelis Dzikir Walisongo. Sumber data primer dalam studi ini adalah jemaah dakwah Majelis Dzikir Walisongo. Pada studi kualitatif tidak dipersoalkan jumlah informan, tetapi bergantung pada tepat tidaknya pemilihan informan kunci, dan kompleksitas dari keragaman fenomena sosial yang diteliti. ${ }^{17}$ Pemilihan informan ditetapkan berdasarkan kriteria jemaah Majelis Dzikir Walisongo yang telah rutin mengikuti kegiatan MDW antara lain: SK (57 tahun) dan bekerja sebagai perias; WD (50 tahun) bekerja sebagai pengelola kedai soto; SD (50 tahun) bekerja sebagai pebisnis travel haji dan umrah; FT (40 tahun) bekerja sebagai kontraktor di Grahapena; STW (49 tahun) ibu rumah tangga; RN (48 tahun) pekerjaan wiraswasta; HY (44 tahun) ibu rumah tangga; NR (50 tahun) seorang ibu rumah tangga; NJ (47 tahun) pekerjaan sebagai pebisnis travel haji dan umrah, NA (57 tahun) seorang wirausaha. Teknik wawancara menggunakan wawancara semi terstruktur. Bentuk observasi yang dilakukan untuk memahami perilaku pasar dakwah MDW adalah observasi tidak terstruktur. Tujuannya agar instrumen pertanyaannya dapat berkembang berdasarkan perkembangan data saat melakukan pengamatan. Observasi dilakukan pada kegiatan pengajian rutin MDW di masjid Ababil, Jalan Gayungsari Surabaya serta interaksi dalam grup jemaah MDW di

17 Rachma Waty Fazry, “Implementasi Kebijakan Ketahanan Pangan Di Kecamatan Cibogo Kabupaten Subang," Dinamika: Jurnal Ilmiah Ilmu Administrasi Negara 6, no. 4 (2019): 365, https://jurnal.unigal.ac.id/index.php/dinamika/article /download/3104/pdf.

18 Philip Kotler and Kevin Lane Keller, Manajemen platform messenger WhatsApp. Hasil deskripsi tentang perilaku jemaah Majelis Dzikir Walisongo dalam mengikuti kajian dakwah MDW divalidasi menggunakan teknik triangulasi sumber dan metode. Data yang dihimpun dari informan dan hasil observasi kemudian dianalisis dengan metode analisis Miles dan Huberman yaitu melalui tahapan reduksi data, penyajian data dan analisis, serta penarikan kesimpulan.

\section{Teori Perilaku Konsumen}

Mempelajari perilaku konsumen adalah mempelajari bagaimana konsumen mengambil keputusan untuk membeli atau mengonsumsi suatu produk. Perilaku konsumen adalah studi bagaimana individu, kelompok dan organisasi memilih, membeli, menggunakan dan menempatkan barang, jasa, ide atau pengalaman untuk memuaskan keinginan dan kebutuhan mereka. ${ }^{18}$ Schifman dan Kanuk dalam Wahyudi dan Prawita menyatakan bahwa perilaku konsumen menggambarkan cara individu mengambil keputusan untuk memanfaatkan sumber daya mereka yang tersedia (waktu, uang, usaha) guna membeli barang-barang yang berhubungan dengan konsumsi. ${ }^{19}$ Menurut Lamb, Hair dan Mc. Daniel menyatakan bahwa perilaku konsumen adalah proses seorang pelanggan dalam membuat keputusan untuk membeli, menggunakan serta mengkonsumsi barangbarang dan jasa yang dibeli, juga termasuk faktor-faktor yang mempengaruhi keputusan pembelian dan penggunaan

Pemasaran, ed. Benyamin Molan, 2nd ed. (Jakarta: Erlangga, 2012), 173.

19 Dedi Wahyudi and Sri Prawita, "Faktor-Faktor Yang Mempengaruhi Perilaku Konsumen Dalam Memilih Sepeda Motor Harley Davidson," Jurnal Ilman: Jurnal IImu Manajemen 1, no. 1 (2014): 84, doi:http://dx.doi.org/10.35126/ilman.v1i1.55. 
produk. ${ }^{20}$ Berdasarkan pendapat tersebut, perilaku konsumen dapat diartikan sebagai respons konsumen terhadap suatu produk termasuk atribut-atribut di dalamnya. Respons tersebut dipengaruhi oleh faktor eksternal maupun internal.

Faktor-faktor yang mempengaruhi perilaku konsumen menurut Kotler dan Armstrong (2008) adalah faktor kebudayaan, sosial, pribadi dan psikologis. ${ }^{21}$ Sejalan dengan itu, Setiadi (2010) dalam Wahyudi dan Prawita ${ }^{22}$ menyatakan bahwa keputusan pembelian sangat dipengaruhi oleh: Faktor Kebudayaan, memberikan pengaruh paling luas dan mendalam pada tingkah laku konsumen. Faktor budaya ini memiliki tiga unsur yang dapat mempengaruhi perilaku konsumen yakni pertama, budaya yang merupakan kumpulan nilai-nilai dasar, persepsi, keinginan, dan tingkah laku yang dipelajari oleh seorang anggota masyarakat dari keluarga atau lembaga penting lainnya. Kedua, adalah sub budaya yang merupakan sekelompok orang dengan sistem nilai terpisah berdasarkan pengalaman dan situasi kehidupan yang umum. Variabel nasionalitas, agama, kelompok ras dan wilayah geografis termasuk ke dalam faktor sub budaya. Ketiga, kelas sosial merupakan pembagian masyarakat yang relatif homogen dan permanen, tersusun secara hierarkis dan para anggotanya menganut nilai-nilai minat dan tingkah laku yang serupa. Kelas sosial ditentukan oleh faktor tunggal seperti pendapatan, tetapi diukur sebagai kombinasi dari pekerjaan,

20 Anang Firmansyah, Perilaku Konsumen (Sikap Dan Pemasaran) (Yogyakarta: Deepublish, 2018), 3.

21 Ellisyah Mindari, "Analisis Faktor-Faktor Yang Mempengaruhi Perilaku Konsumen Dalam Pengambilan Keputusan Pembelian Produk Roti Isi Krim Durian Di Desa Rantau Sialang Kecamatan Sungai Keruh," Jurnal Ekonomika XI, no. 2 (2020): 51, pendapatan, pendidikan dan kekayaan. Pada beberapa sistem sosial, anggota dari kelas yang berbeda memelihara peran tertentu dan tidak dapat mengubah posisi sosial mereka.

Selain faktor kebudayaan, terdapat pula faktor sosial sebagai berikut: Pertama, kelompok sosial yakni dua orang atau lebih berinteraksi mencapai sasaran individu atau bersama. Beberapa kelompok sosial merupakan kelompok primer seperti keluarga, teman, tetangga atau rekan sekerja. Beberapa lainnya merupakan kelompok sekunder yang mempunyai interaksi lebih formal seperti organisasi, kelompok keagamaan, asosiasi profesional dan serikat pekerja. Kedua, faktor keluarga merupakan organisasi yang memiliki pengaruh penting dalam masyarakat dan telah diteliti mendalam, pemasar tertarik dengan peran dan pengaruh suami, istri dan anak-anak pada pembelian berbagai produk dan jasa. Ketiga, peran dan status yakni aktivitas yang diharapkan untuk dilakukan seseorang menurut orang-orang lain yang ada di sekitarnya. Setiap peran membawa status yang mencerminkan penghargaan dari masyarakat. Konsumen seringkali memilih produk yang menunjukkan statusnya dalam masyarakat. ${ }^{23}$

Berikutnya adalah faktor pribadi, didefinisikan sebagai karakteristik psikologis seseorang yang berbeda dengan orang lain yang menyebabkan tanggapan relatif konsisten dan bertahan lama terhadap

http://jurnal.borneo.ac.id/index.php/ekonomika/artic le/view/1437/966.

22 Wahyudi and Prawita, "Faktor-Faktor Yang Mempengaruhi Perilaku Konsumen Dalam Memilih Sepeda Motor Harley Davidson," 85-87.

${ }^{23}$ Ibid. 
lingkungan. Hal-hal yang termasuk ke dalam faktor pribadi adalah pertama, umur dan tahap daur hidup. Orang (konsumen) mengubah konsumsi barang dan jasa yang mereka beli selama masa hidupnya. Selera makanan, pakaian, perabot dan rekreasi sering kali berhubungan dengan umur. Kedua, faktor pekerjaan seseorang yang mempengaruhi barang dan jasa yang dibelinya. Ketiga, situasi ekonomi atau pendapatan juga dapat mempengaruhi pilihan produk. Keempat, gaya hidup, merupakan pola kehidupan seseorang yang diwujudkan dalam aktivitas keseharian misalnya pekerjaan, hobi, berbelanja, olahraga dan kegiatan sosial. Minat seperti, kecenderungan menyukai makanan, mode, dan rekreasi. Opini yang lebih dari sekedar kelas sosial dan kepribadian seseorang. Kelima, kepribadian dan konsep diri. Kepribadian mengacu pada karakteristik psikologi unik yang menyebabkan respons konsisten dan bertahan lama. Umumnya kepribadian diuraikan dalam sifat seperti rasa percaya diri, dominasi, kemudahan bergaul, otonomi, mempertahankan diri, kemampuan menyesuaikan diri, dan keagresifan. $^{24}$

Faktor psikologis merupakan bagian dari pengaruh lingkungan konsumen pada waktu sekarang tanpa mengabaikan pengaruh di masa lampau atau antisipasi terhadap waktu yang akan datang. Hal yang termasuk ke dalam faktor psikologis ini adalah kebutuhan atau motivasi konsumen, persepsi, proses belajar, kepercayaan dan sikap. Faktor kebutuhan, beberapa diantaranya bersifat biogenik yakni timbul dari suatu keadaan

\footnotetext{
24 Ibid.

25 Ibid., 87.

26 Hasanuddin Ali, Lilik Purwandi, and Moh. Firmansyah, "The Potraits Of Urban Moslem
}

fisiologis tertentu seperti rasa lapar, haus, resah, tidak nyaman. Beberapa kebutuhan lainnya bersifat psikogenik yaitu, kebutuhan yang timbul dari keadaan psikologis tertentu, seperti kebutuhan untuk diakui, kebutuhan harga diri atau kebutuhan untuk diterima. Selain faktor kebutuhan, persepsi konsumen juga dapat menjadi faktor yang berpengaruh pada keputusan pembelian konsumen. Persepsi didefinisikan sebagai proses seseorang memilih, mengorganisasikan, mengartikan masukan informasi untuk menciptakan suatu gambaran berarti dari dunia ini (realitas). Faktor proses belajar menjelaskan perubahan perilaku yang timbul karena pengalaman. Faktor kepercayaan dan sikap adalah gagasan deskriptif yang dimiliki seseorang terhadap sesuatu. ${ }^{25}$

\section{Masyarakat Muslim Perkotaan (Urban Muslim)}

Masyarakat kota adalah masyarakat yang terbuka, mereka cenderung terbuka terhadap segala aspek pemikiran termasuk pemikiran tentang keagamaan. Di Indonesia pertumbuhan populasi masyarakat kota (urban population) sebesar $4.2 \%$ per tahun yang telah melebihi China dan India sebagai negara dengan jumlah penduduk terbesar di dunia. ${ }^{26} \mathrm{Hal}$ ini, menunjukkan bahwa potensi masyarakat muslim kota cukup besar sebagai mitra dakwah karena jumlahnya yang terus bertumbuh.

Ada perbedaan yang sangat mendasar antara muslim desa yang cenderung

Indonesia" (Jakarta, July 2015), 3, https://www.researchgate.net/publication/31444894 9_The_Potraits_Of_Urban_Moslem_Indonesia. 
tradisional dan statis dan muslim kota yang cenderung lebih dinamis. Masyarakat desa adalah masyarakat agraris, dimana kehidupan mereka ditopang oleh alam. Struktur sosial masyarakat desa cenderung homogen, mereka adalah masyarakat yang monokultur, memegang teguh tradisi dan nilai-nilai sakral sehingga cenderung tertutup pada pemikiran-pemikiran baru, sehingga kehidupan keberagamaan masyarakat desa sangat mudah diprediksi. Ini berbeda dengan kehidupan keagamaan masyarakat kota yang multikultur. ${ }^{27}$ Oleh sebab itu, berdakwah pada masyarakat muslim kota memiliki tantangan tersendiri.

Lingkungan perkotaan menawarkan beragam kemudahan akses kepada masyarakatnya. Menurut temuan hasil riset yang dilakukan Alvara Research Center, masyarakat yang hidup di lingkungan perkotaan didominasi oleh kelompok kelas menengah. Mayoritas kelas menengah hidup di kota karena merupakan pusat ekonomi dan bisnis. Di kota ada kemudahaan terhadap akses lapangan kerja, akses pendidikan, akses sumber daya dan sebagainya. ${ }^{28}$ Berdasarkan fakta tersebut, dapat diartikan mayoritas masyarakat muslim kota merupakan muslim kelas menengah.

Hasil survey Alvara Research Center menemukan bahwa lebih dari separuh kelas menengah muslim (59.7\%) dekat dengan ormas Nahdlatul Ulama (NU), kemudian diikuti oleh ormas Muhammadiyah (11.0\%), sedangkan yang merasa tidak dekat dengan

\footnotetext{
27 Ibid.

28 Hasanuddin Ali and Lilik Purwandi, "Indonesia Middle Class Moslem: Religiosity and Consumerism" (Jakarta, February 2017), 7, https://alvarastrategic.com/whitepaper-indonesia-middle-classmuslim-religiosity-and-consumerism/.
}

ormas manapun sebesar 26\%. Kedekatan kelas menengah muslim dengan ormas NU bisa disebabkan memang karena pengaruh keluarga dekat atau orang tua yang sudah dekat dengan NU, maupun karena tertarik dan nyaman dengan ajaran-ajaran moderasi kelslaman yang diusung oleh NU. Masyarakat NU selama ini lebih identik dengan masyarakat tradisionalis, yaitu masyarakat yang cenderung tinggal di desa dan juga masyarakat dengan pendidikan rendah. Melihat temuan hasil riset ini tentunya menjadi hal yang menarik, bahwa masyarakat modern (masyarakat kelas menengah) juga dekat dengan NU. ${ }^{29}$

Pada tahun 2019, Alvara Research Center kembali menerbitkan hasil riset potret keberagamaan masyarakat muslim di Indonesia dan menghasilkan temuan sebagai berikut ${ }^{30}$ : Pertama, Umat muslim di Indonesia merupakan masyarakat religius. Sebanyak $80,2 \%$ responden dalam riset tersebut menyatakan bahwa agama sangat penting dalam kehidupan. Agama menjadi sangat penting seiring dengan pertambahan usia, khususnya pada generasi yang saat ini usianya 30 sampai dengan 55 tahun. Kedua, mayoritas umat muslim Indonesia terkait praktik ibadah ritual menjalankan tahlil $(82,2 \%)$, maulid nabi $(88,6 \%)$, qunut subuh (73,6\%), dan juga ziarah kubur $(64,7 \%)$. Berdasarkan hasil perbandingan praktik keagamaan generasi tua dengan generasi muda, ditemukan fakta bahwa generasi tua lebih banyak melaksanakan ritual keagamaan yang sifatnya kultural dan diajarkan turun temurun seperti tahlilan,

\footnotetext{
${ }^{29}$ Ali and Purwandi, "Indonesia Middle Class Moslem: Religiosity and Consumerism."

30 Hasanuddin Ali and Lilik Purwandi, "Indonesia Muslim Report 2019" (Jakarta, December 2019), 5-14, https://alvara-strategic.com/indonesia-muslim-report2019/.
} 
ziarah kubur, qunut subuh, maulid nabi. Hal ini, menunjukkan praktik ibadah ritual mayoritas muslim di Indonesia mengikuti amalan organisasi NU. Ketiga, muslim di Indonesia menyatakan paling dekat dengan organisasi NU sehingga NU memiliki jumlah pengikut paling tinggi $(39,2 \%)$, berikutnya adalah Muhammadiyah (7,4\%) dan Nahdlatul Wathan (1,8\%). Hal ini menunjukkan bahwa organisasi NU merupakan organisasi yang menjadi preferensi umat Islam di Indonesia. Keempat, adanya ustaz atau ulama di lingkungan tempat tinggal masih menjadi sumber informasi keagamaan yang utama bagi umat Islam di Indonesia, setelahnya adalah orang tua, guru agama dan Youtube bagi yang berusia muda.

Di lain sisi, Howel dalam Anis menjelaskan bahwa telah berkembang gerakan spiritual di wilayah perkotaan di Indonesia yang kemudian disebut dengan praktik urban sufisme. $^{31}$ Yakni perilaku sufisme yang terjadi pada masyarakat Urban. Ari Ginanjar Agustian dalam seminarnya menyampaikan temuan studi terbaru tentang gaya hidup para sufi di abad 21 yang mencengangkan. Para sufi di zaman modern saat ini tidak ditemukan di masjid atau di goa dengan menyendiri dan berzikir namun ditemukan di tengah hiruk pikuk perkotaan. ${ }^{32} \mathrm{Hal}$ ini, menunjukkan bahwa telah ditemukan indikasi perilaku yang mengarah pada praktik pencarian spiritualitas ala sufi pada masyarakat muslim perkotaan namun dengan wajah yang berbeda yakni lebih

\footnotetext{
${ }^{31}$ Anis, "Spiritualitas Di Tengah Modernitas Perkotaan," 1.

${ }^{32}$ Lilis Andarwati, "Sufisme Perkotaan Dan Pedesaan Di Era Modernisasi Dan Sekularisasi," Universum 10, no. 1 (2016): 44, doi:10.30762/universum.v10i1.222.

33 Jati, "Sufisme Urban Di Perkotaan: Konstruksi Keimanan Baru Kelas Menengah Muslim," 175.
}

modern artinya tidak benar-benar meninggalkan duniawi sebagaimana paham sufisme yang dikenal sebelumnya.

Sufisme dapat diartikan sebagai bentuk ritual untuk mendekatkan diri secara intim kepada Sang Khalik. Pendekatan diri tujuannya adalah upaya mencari ketenangan dan juga solusi atas segala permasahan hidup. Pada umumnya, orang menjalani kegiatan sufisme untuk mencari solusi penyelesaian masalah setelah rasio dan akal sendiri tidak berhasil dalam penyelesaiannya. Hal itulah, yang kemudian mendorong masyarakat mencari solusi permasalahan melalui jalan spiritual. ${ }^{33} \mathrm{Hal}$ ini, menjadi penjelas bahwa spiritualisme begitu didambakan oleh masyarakat muslim di perkotaan.

Tingginya dorongan pemenuhan kebutuhan spiritual pada masyarakat urban dikarenakan masyarakat yang tinggal di wilayah perkotaan (masyarakat urban) rentan terdampak masalah sosial yang mengakibatkan stres. Kondisi psikologis yang negatif mudah sekali timbul dalam kondisi lingkungan yang padat dan sesak. Kondisi psikologis yang negatif merupakan faktor penunjang yang kuat untuk munculnya stres. ${ }^{34}$ Menurut Burton dan Evans dalam Desy, Defiana dan Ruth menjelaskan bahwa, paradigma stres telah secara khusus diterapkan pada studi mengenai kepadatan dan kebisingan yakni, kondisi yang terkait

\footnotetext{
${ }^{34}$ R. P. Sari, D. K., Gunawan, D. \& Septiani, “Gambaran Coping Stress Pada Pendatang Baru Yang Tinggal D Lingkungan Padat Dan Bising Di Jakarta," Psikoislamedia Jurnal Psikologi 3, no. 2548-4044 (2018): 126 , doi:http://dx.doi.org/10.22373/psikoislamedia.v3i2.5 619.
} 
dengan lingkungan perkotaan. ${ }^{35} \mathrm{Hal}$ ini, memicu individu untuk melakukan upaya untuk menyelesaikan masalah stres dengan jalan mencari ketenangan.

Studi tentang urban sufisme telah banyak dilakukan pada kelas menengah muslim perkotaan di Indonesia. Hal ini, dikarenakan jumlah kelas menengah di lingkungan masyarakat perkotaan terus bertumbuh. Praktik urban sufisme sendiri ditengarai muncul sebagai ekspresi kelas menengah muslim perkotaan. ${ }^{36}$ Jika sufisme tradisional lebih menekankan pada aspek ikatan tradisional sebagai jalan menuju Tuhan, maka sufisme urban lebih menekankan pada pola solutif yang berfokus pada kebutuhan ruhani sebagai jalannya. ${ }^{37}$

\section{Majelis Dzikir Walisongo}

Majelis Dzikir Walisongo merupakan kegiatan pengajian yang digagas oleh organisasi NU, sehingga dapat dipastikan bahwa konten dakwah yang disajikan berkarakter paham ahlusunah waljamaah. Produk dakwah dalam pengajian tersebut tentunya tidak meninggalkan tradisi yang sudah lama dilestarikan oleh NU kaitannya dengan melestarikan nilai ajaran ahlusunah waljamaah. MDW juga melayani konsultasi keagamaan bagi jemaah secara langsung melalui tanya jawab saat kegiatan pengajian berlangsung maupun setelah pengajian dengan cara jemaah bertanya secara privat pada ustaz pemateri. Konsultasi keagamaan juga dapat dilakukan dalam interaksi di grup WhatsApp jemaah pengajian MDW. Semua

\footnotetext{
35 Ibid.

36 Jati, "Sufisme Urban Di Perkotaan: Konstruksi Keimanan Baru Kelas Menengah Muslim," 178.

${ }^{37}$ Ibid., 179.

${ }^{38}$ ER (Pengurus LDNU), Wawancara oleh Siti, tanggal 1
}

pengurus LDNU yang merupakan dai bergabung dalam grup WhatsApp tersebut bersama jemaah. Jemaah dipersilahkan bertanya bila ada wawasan keagamaan yang ingin diketahui. Apabila tidak nyaman berkonsultasi dengan cara bertanya langsung di grup jemaah, maka jemaah dapat menghubungi secara pribadi nomor kontak dai yang ada di grup tersebut. ${ }^{38}$

Pengajian MDW dilaksanakan secara rutin dua kali dalam sebulan, setiap hari minggu tepat pukul 08.00 WIB dan selesai pada pukul 10.00 WIB. Pengajian di mulai dengan pembacaan selawat nabi, kemudian istigasah (zikir bersama) dengan dipandu seorang imam zikir. Berikutnya disambung dengan tausiah, muhasabah (renungan) dan doa bersama, kemudian acara hiburan berupa penampilan seni hadrah dari jemaah secara bergantian. Konsep kegiatan MDW adalah memadukan zikir dan tausiah dengan sentuhan motivasi dan pencerahan kepada umat agar selalu optimis dan bersyukur menikmati kehidupan dunia dan menyongsong kemantapan kehidupan akhirat. $^{39}$

Ceramah agama (tausiah) yang dilaksanakan dalam kajian, materi dan tema disesuaikan dengan permasalahan mad'uw atau jemaah, dapat bersifat mengingatkan akan nilai-nilai ajaran yang benar (yang sebelumnya nilai tersebut diketahui jemaah), namun dapat pula bersifat menambah atau memberikan wawasan baru seputar keislaman kepada jemaah. Selain tausiah, ada pula kegiatan istigasah (zikir dan doa bersama). Ditinjau dari segi etimologi, berasal dari kata Istighotsah, bentuk mashdar dari Fi'il Madli

Februari 2017.

39 ER (Pengurus LDNU), Wawancara oleh Siti, tanggal 1 Februari 2017. DW (Ketua Majelis Dzikir Walisongo), Wawancara oleh Siti, tanggal 24 April 2017. 
Istaghotsa yang berarti mohon pertolongan. Adapun bila ditinjau dari segi Terminologi, Istigotsah ialah beberapa bacaan wirid tertentu yang dilakukan untuk mohon pertolongan kepada Allah SWT. Atas beberapa masalah hidup dan kehidupan yang dihadapi. Kegiatan ini mulai banyak dikenal oleh masyarakat khususnya kaum Nahdliyyin (sebutan bagi Jamiah NU atau jemaah dakwah NU) pada kisaran tahun 1990. Di Jawa Timur, ulama yang ikut mempopulerkan kegiatan istighotsah atau istigasah adalah almarhum $\mathrm{KH}$ Imron Hamzah (Rais Syuriyah PWNU Jatim). ${ }^{40}$ Menurut informasi tersebut, kegiatan istigasah ini merupakan kegiatan yang lazim dilaksanakan oleh organisasi NU dan diketahui oleh semua jemaah dakwah NU yang disebut dengan jamiah.

Dai yang rutin menjadi pemateri dan memberikan tausiah pada kegiatan pengajian MDW dikenal oleh jemaah sebagai dai yang banyak disukai jemaahnya karena memiliki perangai yang humoris, ramah, sabar khususnya dalam menjawab permasalahan mad'uw seputar pemahaman keagamaan yang dikonsultasikan kepadanya. Gaya penyampaian dakwah beliau humoris namun mencerahkan. Kemampuannya dalam mengajak jemaah majelis taklim doa bersama seusai kegiatan ceramah agama, membuat jemaah antusias apabila ada kegiatan pengajian yang disampaikan oleh beliau. ${ }^{41}$ Secara tidak langsung, eksistensi dai dengan kualifikasi dan kompetensinya pada kegiatan dakwah MDW berperan cukup penting yang

\footnotetext{
40 Ishomuddin Ma'shum, "Siapa Penyusun Bacaan Istighotsah?," NU Online, 2013, https://www.nu.or.id/post/read/47541/siapapenyusun-bacaan-istighotsah.

${ }^{41}$ DW (Ketua Majelis Dzikir Walisongo), Wawancara oleh Siti, tanggal 24 April 2017.
}

mempengaruhi respons positif jemaah terhadap kegiatan dakwah MDW.

Adapun untuk mengapresiasi talenta jemaah yang memiliki kemampuan menampilkan seni hadrah, MDW juga menampilkan seni hadrah yang penampilnya merupakan anggota dari jemaah sendiri. Kegiatan hadrah ini, juga bertujuan untuk memberikan hiburan bagi jemaah yang mengikuti kajian MDW agar mereka tidak merasa bosan. ${ }^{42}$ Berdasarkan data tersebut, dapat disimpulkan secara produk, kegiatan dakwah yang diselenggarakan MDW memiliki atribut ceramah agama atau tausiah, istigasah (zikir dan doa bersama), konsultasi keagamaan baik secara langsung maupun tidak langsung, dai yang kompeten dalam menyampaikan materi kajian serta memimpin zikir dan doa bersama dan hiburan berupa penampilan seni hadrah.

Mayoritas Jemaah MDW adalah perempuan, meskipun ada beberapa jemaah yang lakilaki. Saat dilakukan observasi pada acara taklim MDW di masjid Ababil, jemaah berjenis kelamin laki-laki hanya beberapa orang yang duduk melingkar di barisan depan saja. Sedangkan, untuk jemaah perempuan jumlahnya jauh lebih banyak, terlihat sampai membutuhkan keluar ruang utama masjid. Secara usia rata-rata 40 hingga 50 tahun. Ada anggota jemaah yang paling muda, yakni anak dari salah seorang jemaah MDW. ${ }^{43}$ Media yang digunakan oleh mereka sebagaimana karakter masyarakat urban yang cukup adaptif dengan perkembangan teknologi, maka medianya

\footnotetext{
42 ER (Pengurus LDNU), Wawancara oleh Siti, tanggal 1 Februari 2017

43 FT (jemaah MDW), Wawancara oleh Siti, tanggal 5 Mei 2017.
} 
menggunakan WhatsApp dan handphone.

Untuk melakukan koordinasi dan mengirimkan undangan kegiatan MDW juga melalui media tersebut.

\section{Perilaku Pasar Dakwah Muslim Perkotaan dalam Pengajian Majelis Dzikir Walisongo}

Gaya Hidup Sering Menghadiri Pengajian

Jemaah sebagian besarnya telah mengikuti pengajian di luar pengajian MDW. Data ini dibuktikan dengan salah satu jemaah MDW berinisial SK (57 tahun) menyatakan sering mengikuti pengajian, istigasah, dan tahlil di kampungnya hingga diajak oleh rekan seprofesinya untuk ikut kajian MDW. ${ }^{44}$ WD (50 tahun) yang juga merupakan jemaah pengajian PESONA (merupakan singkatan dari Pecinta Selawat Nabi) ASWAJA. ${ }^{45}$ SD (50 tahun) merupakan jemaah MDW yang juga mengikuti pengajian rutin di kampung Bangkingan dan masjid Al-Akbar Surabaya ${ }^{46}$ serta masih banyak lagi lainnya. Alasanalasan yang dikemukakan jemaah mengikuti banyak kegiatan pengajian adalah untuk menambah spiritualitas, mendekatkan diri kepada Tuhan sang pencipta sehingga mereka mendapatkan ketenangan batin dari peningkatan spiritualitas tersebut. Mereka menyukai kegiatan ceramah agama atau tausiah karena menganggap manfaatnya adalah menjadi pengingat akan nilai-nilai tauhid kepada jemaah. Hal inilah, menjadi asumsi dasar mereka merespons secara positif kegiatan Majelis Dzikir Walisongo

44 SK (Jemaah Majelis Dzikir Walisongo), Wawancara Oleh Siti, Tanggal 5 Mei 2017.

45 WD (Jemaah Majelis Dzikir Walisongo), Wawancara Oleh Siti, Tanggal 5 Mei 2017

${ }^{46}$ SD (Jemaah Majelis Dzikir Walisongo), Wawancara Oleh Siti, Tanggal 5 Mei 2017. yakni karena jemaah sebagian besarnya sudah memiliki gaya hidup yang agamis dengan rutin menghadiri pengajian. Adapun pengajian yang diikuti rata-rata merupakan pengajian berpaham ahlusunah waljamaah serupa dengan pengajian Majelis Dzikir Walisongo. ${ }^{47}$

Respons positif jemaah terhadap kajian Majelis Dzikir Walisongo ditunjukkan dengan mereka berkomitmen untuk hadir setiap kali pengadaan pengajian MDW meskipun sebenarnya beberapa masih ada kendala terkait bentrok jadwal dengan kegiatan lain yang juga dianggap penting misalnya bekerja. Pasalnya, hari minggu ada beberapa jemaah yang terpaksa harus bekerja. Salah seorang jemaah yang berprofesi sebagai perias pengantin mengaku cukup sering mendapatkan pesanan jasa rias pengantin pada hari libur (minggu) saat kajian MDW diadakan. ${ }^{48}$ Seorang pedagang yang memiliki usaha warung makan, yang warungnya banyak dikunjungi pelanggan pada hari libur (minggu) tetap memiliki komitmen untuk datang pada setiap kegiatan pengajian karena adanya pandangan sebaiknya memprioritaskan kegiatan keagamaan untuk keperluan akhirat dibanding duniawi. ${ }^{49}$ Maka, perilaku mereka tetap mengupayakan untuk datang pada waktu yang sudah ditentukan oleh pengurus Majelis Dzikir Walisongo.

\section{Pemenuhan Kebutuhan Spiritualitas adalah Prioritas}

Atribut produk tausiah dengan materi dakwah yang ringan serta menyentuh

\footnotetext{
47 SK, WD, SD (Jemaah Majelis Dzikir Walisongo), Wawancara Oleh Siti, Tanggal 5 Mei 2017.

48 SK (Jemaah Majelis Dzikir Walisongo), Wawancara Oleh Siti, Tanggal 5 Mei 2017.

49 WD (Jemaah Majelis Dzikir Walisongo), Wawancara Oleh Siti, Tanggal 5 Mei 2017.
} 
realitas keseharian mereka membuat mereka menyukai kegiatan dakwah yang diselenggarakan oleh MDW. Hal ini, karena permasalahan kehidupan mereka sebagai masyarakat urban sudah sangat kompleks, sehingg cenderung menginginkan tema materi yang mudah dipahami serta menyentuh realitas keseharian mereka. Selain produk tausiah, dalam konteks kegiatan pengajian MDW, terdapat atribut produk istigasah dan zikir bersama yang juga dianggap oleh jemaah berkontribusi meningkatkan spiritualitas mereka. Spiritualitas disini bermakna perasaan dekat kepada Allah dan adanya ketenangan secara psikologis bila melibatkan diri dalam kegiatan peribadatan, yakni mendengarkan tausiah, berzikir dan istigasah. Jemaah merasa senang karena bisa seperti mengadukan kesulitan hidupnya atau "curhat" dengan Allah dan memohon agar Allah memudahkan segala urusan yang mereka kerjakan. Jemaah juga menangis saat melakukan kegiatan muhasabah dan doa bersama dalam pengajian. Sebenarnya aktivitas muhasabah dan doa bersama ini dapat saja dilakukan jemaah secara mandiri, namun ketika dilakukan bersama dipandu oleh dai yang mampu membawakan suasana penuh penghayatan dipandang dapat memberikan suasana psikologis yang lebih "melegakan". Seolah mereka tidak sendirian menghadapi kesulitan hidup, setelahnya sesama anggota jemaah yang hadir dapat saling memotivasi satu sama lain. ${ }^{50}$

Pemenuhan kebutuhan spiritualitas juga diperoleh jemaah dengan adanya dai yang berkualitas dalam menyampaikan tausiah. Jemaah menyampaikan bahwa dai pemateri

${ }^{50}$ ER (Pengurus LDNU), Wawancara oleh Siti, tanggal 14 Juni 2017.

51 SD, HY, FT (Jemaah Majelis Dzikir Walisongo), kajian dakwah di Majelis Dzikir Walisongo merupakan dai yang piawai dalam menyampaikan materi tausiah, pembawaannya tidak kaku dan diselingi oleh humor, sehingga tidak terkesan monoton dan membosankan. Sebagai imam zikir, pada kegiatan zikir dan doa bersama di akhir acara pengajian, dai MDW dipandang sebagai dai yang pandai membawa suasana penghayatan spiritual. Jemaah MDW dibuat terhanyut dalam suasana spiritual dan perenungan mendalam saat proses muhasabah (renungan dan doa bersama) yang dipandu oleh ER salah satu ustaz kajian MDW. Jemaah dapat menangis tersedu-sedu karena mengingat dosa-dosa yang selama ini mereka perbuat. $^{51}$ Sehingga, setiap kali jemaah MDW mengetahui informasi bahwa yang akan menjadi pemateri kajian dan pemandu muhasabah adalah ER, maka mereka menyiapkan tisu sejak sebelum kajian untuk menyeka air mata saat momentum muhasabah. ${ }^{52}$ Jemaah yang menjadi informan secara keseluruhan juga menilai tertarik mengikuti kajian MDW karena ustaznya baik (berkualitas) dalam berdakwah.

Selain menyukai tausiah karena aspek manfaat spiritualitas yang diperoleh, jemaah juga menyampaikan telah mendapatkan manfaat menambah wawasan Islam dari adanya tausiah dalam pengajian MDW. Hal ini, senada dengan keterangan pengurus, bahwa jemaah telah mendapatkan solusi atas permasalahan yang mereka hadapi dalam keseharian yang membutuhkan pemecahan dari nilai agama. Lebih lanjut beliau menyampaikan bahwa sering kali dijumpai mad'uw berkonsultasi seputar

Wawancara Oleh Siti, 29-30 April 2017.

52 DW (Ketua Majelis Dzikir Walisongo), Wawancara oleh Siti, tanggal 29 April 2017. 
materi dan pemecahan dalam sudut pandang keagamaan kepada pengisi kajian MDW setelah kajian selesai baik secara langsung maupun melalui pesan pribadi kepada dai. ${ }^{53}$ Hanya saja, menurut salah seorang jemaah berinisial NA (57 tahun), materi yang disampaikan kadang sama saja dan sudah pernah diterima mereka ketika mengikuti pengajian lainnya (di luar kajian MDW), akan tetapi mereka tidak mempermasalahkan karena yang dibutuhkan adalah pengondisian nilai Islam dari tausiah tersebut. Apalagi wawasan Islam yang sudah pernah disampaikan dalam tausiah terkadang bisa terlupakan jika tidak ada yang mengingatkan kembali. ${ }^{54} \mathrm{Hal}$ ini, menunjukkan bahwa manfaat spiritualitas yang berupa pengondisian nilai islami lebih utama dibanding dengan wawasan keislaman. Sebagaimana konsep masyarakat muslim perkotaan yang mengalami dinamika masalah sosial demikian kompleks hingga menumpuk tekanan psikologis dan rentan terhadap gangguan stress, mereka mencari jalan pemecahan melalui zikir dan kegiatan penambah spiritualitas agar merasa lebih tenang. Gejala perilaku menyukai zikir dan kegiatan dakwah untuk meningkatkan manfaat spiritualitas ini serupa dengan karakteristik masyarakat urban dalam studi terdahulu yakni perilaku yang menerapkan urban sufisme.

Studi yang dilakukan Wasisto Raharjo Jati, tentang fenomena urban sufisme pada kalangan kelas menengah perkotaan memberikan gambaran bahwa, sufisme memang digunakan sebagai upaya untuk mencari ketenangan dan mencari solusi hidup sementara. Praktek ibadah yang

${ }^{53}$ ER (Pengurus LDNU), Wawancara oleh Siti, tanggal 17 Juni 2017.

${ }^{54}$ NA (Jemaah Majelis Dzikir Walisongo), Wawancara mengedepankan zikir dan selawat yang memberikan ketenangan banyak diminati oleh masyarakat muslim kota. Perilaku sufisme tersebut memang tidak dapat dilepaskan dari tingkat stress kehidupan yang tinggi pada masyarakat perkotaan. Fenomena yang sama teramati dalam jemaah pengajian MDW yang merespons positif kegiatan dakwah MDW, karena variabel dapat memenuhi kebutuhan spiritualitas yang berkaitan dengan ketenangan batin, merasa dekat dengan Allah dan bisa mengadukan segala permasalahan hidup kepada Allah Swt. Selanjutnya dalam studi tersebut, juga disebutkan bahwa pengaruh modernitas lingkungan perkotaan menciptakan keresahan bagi kehidupan masyarakat perkotaan. Keresahan tersebut memunculkan sikap alienasi dan akhirnya mencari agama sebagai solusi. Artinya, dalam masyarakat muslim perkotaan berlaku High Tech High Touch yakni semakin tinggi teknologi berkembang semakin berkembang pula kebutuhan rohani. Hal ini, secara signifikan menjelaskan hadirnya sufisme. ${ }^{55}$ Pada konteks karakteristik respon jemaah terhadap kajian dakwah MDW yang mementingkan pemenuhan kebutuhan spiritual bahkan jika dibandingkan wawasan yang didapatkan dari kajian menunjukkan berlakunya prinsip high tech high touch.

\section{Kegiatan Pengajian Menciptakan Ruang Bersosialisasi Bagi Jemaah.}

Selain manfaat spiritual dan wawasan Islam, jemaah juga merespons positif kegiatan MDW karena komunitas pengajian MDW sendiri merupakan wadah bagi berkumpulnya jemaah pengajian dari

oleh Siti, tanggal 39 April 2017.

55 Jati, "Sufisme Urban Di Perkotaan: Konstruksi Keimanan Baru Kelas Menengah Muslim," 177. 
beragam kelompok pengajian di Surabaya. Umumnya, kelompok pengajian diselenggarakan berdasarkan lokal wilayah kampung, RT/RW setempat atau masih satu wilayah berdekatan seperti daerah Surabaya Timur, Surabaya Barat, dan lain sebagainya, namun Majelis Dzikir Walisongo lintas wilayah bahkan beberapa jemaah ada yang berasal dari luar kota Surabaya. Adanya pengajian yang diikuti oleh beberapa kelompok pengajian ini, mampu membangun ikatan persaudaraan sesama muslim yang lebih kuat dan lebih luas. Jemaah menyukai kegiatan MDW karena dapat mengenal saudara sesama muslim yang sama-sama menyukai kegiatan pengajian, sebab sebelum bergabung dan mengikuti kajian MDW mereka hanya bersosialisasi dengan anggota jemaah pengajian dari lingkungan terdekat mereka saja (lingkungan kampung). Data ini, dibuktikan dengan adanya permintaan jemaah pada pengurus untuk membuatkan jemaah seragam khusus pengajian MDW. Seragam tersebut dipakai jemaah untuk menghadiri pengajian MDW. Realisasinya, pengurus MDW hanya membuatkan kerudung panjang (mirip seperti khimar) berwarna putih dengan tulisan Majelis Dzikir Walisongo di bagian belakang untuk jemaah perempuan.

Salah satu jemaah berinisial NA, asal dari Kenjeran, Surabaya menyampaikan bahwa ingin sesekali di kegiatan MDW mengadakan kegiatan seperti ziarah wali agar jemaah bisa lebih saling mengenal. Kegiatan ziarah wali selain mendatangkan pahala juga memberi penghiburan bagi jemaah di tengah kepadatan aktivitas mereka sehari-hari. ${ }^{56} \mathrm{Hal}$ ini, juga pernah disampaikan oleh pengurus,

\footnotetext{
56 NA (Jemaah MDW), Wawancara oleh Siti, tanggal 6
} Mei 2017 yang mendapatkan saran dari jemaah agar MDW mengadakan kegiatan bersama tidak hanya ngaji (pengajian) saja, melainkan kegiatan lainnya seperti ziarah wali. ${ }^{57}$ Pada satu kesempatan, terjadi interaksi jemaah yang menyambut antusias ajakan temantemannya sesama jemaah melakukan kegiatan wisata kuliner. Kegiatan tersebut dilakukan secara spontan oleh jemaah setelah kegiatan pengajian MDW sudah selesai dilaksanakan. Jemaah yang mayoritas wanita tersebut sangat senang dengan ide berwisata kuliner dan saling memberikan saran lokasi wisata kuliner yang akan mereka kunjungi. Walaupun tidak semua jemaah turut serta dalam kegiatan wisata kuliner tersebut. Setelah melakukan wisata kuliner, jemaah mengunggah foto-foto kebersamaan mereka di grup WhatsApp jemaah MDW. Berdasarkan fenomena tersebut, terdapat indikasi adanya kebutuhan jemaah yang merupakan masyarakat urban untuk bersosialisasi dengan orang lain khususnya mereka yang memiliki karakteristik sama yakni sesama anggota pengajian. Jika merujuk pada karakteristik masyarakat perkotaan yang umumnya memiliki sisi individualitas cukup besar, karena memburu materi dan kepentingan duniawi, hal ini merupakan fenomena baru di luar praktik sufisme masyarakat urban yang didasari oleh kebutuhan spiritualitas. Kebutuhan sosial menjadi hal yang ingin dipenuhi dari kegiatan pengajian barangkali muncul dari kondisi alienasi yang dialami oleh masyarakat perkotaan. Howel dalam Muhammad Anis, menyatakan bahwa peningkatan penduduk kota yang cepat, penyebaran pendidikan umum non religius dan ilmu alam, peningkatan mobilitas dan akses informasi, industrialisasi telah

${ }^{57}$ ER (Pengurus LDNU), Wawancara oleh Siti, tanggal 17 juni 2017. 
mendatangkan tekanan bagi masyarakat kota. Kemakmuran materi, gaya hidup serba instan yang tidak sehat, serta kurangnya waktu untuk memelihara kebersamaan bersama keluarga dan bersosialisasi justru telah mengalienasi manusia modern dari diri mereka sendiri. ${ }^{58}$ Jalan keluar untuk mengatasi alienasi yang ada pada masyarakat selain mengarah pada pencarian pemenuhan kebutuhan spiritual, juga mengarah pada pemenuhan kebutuhan sosial. Adanya perlibatan diri pada kegiatan komunitas termasuk pengajian, membuat mereka memiliki ikatan kelompok yang bisa memenuhi kebutuhan sosial tersebut. Hal ini, dikuatkan dengan adanya perintah dalam ajaran Islam untuk mengembangkan ikatan persaudaraan sesama muslim yang dikenal dengan konsep ukhuwah islamiah, sehingga jemaah memiliki perasaan positif terhadap kegiatan bersosialisasi pada Majelis Dzikir Walisongo.

\section{Faktor yang Mempengaruhi Respons Jemaah terhadap Kajian Dakwah}

Berdasarkan data respons jemaah terhadap atribut produk dakwah MDW, dapat dianalisis faktor-faktor yang mempengaruhi perilaku mereka, sebagai berikut:

Faktor kebudayaan terdiri dari nilai budaya, sub budaya, dan kelas sosial. Budaya merupakan sekumpulan nilai dan norma sosial yang ada pada lingkungan masyarakat. Jemaah MDW merupakan masyarakat yang tinggal di wilayah perkotaan, sehingga termasuk dalam kategori masyarakat muslim perkotaan atau masyarakat urban. Secara tidak langsung, adanya budaya di lingkungan masyarakat seperti urban sufisme dan prinsip High Tech High Touch turut memberikan pengaruh pada jemaah sehingga mereka pun tinggi pemenuhan spiritualitasnya. Identitas jemaah sebagai anggota jamiah NU mempengaruhi perilaku jemaah dalam memilih bentuk pemenuhan kebutuhan spiritualnya yakni melalui zikir dan istigasah sebagaimana hal tersebut telah membudaya dalam organisasi NU. Identitas jamiah NU menjadi faktor sub budaya yang mempengaruhi bentuk respons jemaah terhadap kajian dakwah. Faktor sub budaya jemaah berupa nilai-nilai ahlusunah waljamaah juga mempengaruhi praktik sufisme urban yang mereka terapkan, seperti mustahil untuk mengarah pada bentuk fundamentalisme atau ekstrim. Untuk faktor kelas sosial tidak ditemukan data yang menjelaskan bahwa kelas sosial jemaah mempengaruhi bentuk respons mereka terhadap produk dakwah.

Faktor sosial terdiri dari kelompok sosial, keluarga, peran dan status. Fakta bahwa jemaah MDW berasal dari lintas komunitas pengajian menunjukkan bahwa, adanya pengaruh faktor sosial yakni kelompok sosial sebagai acuan untuk mengikuti kajian. Jemaah dengan inisial NA mengaku sebagai ketua pengajian di kampungnya, kemudian setelah mengetahui keberadaan MDW, beliau bersemangat mengajak jemaah pengajian kampungnya untuk menghadiri pengajian MDW. Hal ini, menunjukkan komunitas pengajian kampung menjadi kelompok sosial acuan bagi jemaah untuk mengikuti kajian MDW. Selain komunitas pengajian kampung di sekitar lingkungan rumah tinggal jemaah, adapula kelompok sosial jamiah NU mempengaruhi pilihan

${ }^{58}$ Anis, "Spiritualitas Di Tengah Modernitas Perkotaan," 
kegiatan pengajian harus sepaham dengan nilai dakwah dan pemikiran NU. Adanya penerimaan terhadap ajakan rekan seprofesi mengikuti kajian MDW, juga tidak dapat diabaikan sebagai salah satu faktor kelompok sosial yang berpengaruh terhadap respons jemaah. Untuk faktor keluarga memberikan pengaruh dapat terjelaskan dengan data, bahwa jemaah mengajak serta pasangan dan anaknya untuk ikut kegiatan MDW, walaupun tidak semuanya berhasil diajak ikut. Seperti misalnya, salah satu jemaah berinisial SD mengikuti rutin kajian MDW karena diajak oleh suaminya yang merupakan ketua MDW, beliaupun kemudian mengajak anak perempuannya untuk ikut serta dalam pengajian MDW. Perihal faktor peran dan status di masyarakat yang mempengaruhi ketertarikan jemaah mengikuti kajian dakwah, tidak ditemukan data yang mengarah pada analisis tersebut.

Faktor pribadi terdiri dari umur dan tahap daur hidup, faktor pekerjaan, faktor situasi ekonomi atau pendapatan, dan faktor gaya hidup yang meliputi kebiasaan, minat dan opini. Perilaku jemaah dalam mengikuti kajian juga dipengaruhi oleh usia mereka. Jemaah MDW mayoritas merupakan orang yang berada pada rentang usia lanjut. Meskipun manajemen LDNU tidak secara tegas memberikan batasan usia bagi jemaah yang boleh mengikuti pengajian MDW. Pada faktanya, mad'uw yang berusia muda hanya sedikit orang, lebih banyak yang berada di usia tua. Berdasarkan temuan studi yang dilakukan Daaleman, Perera dan Studentski dalam Zakiyah, orang lanjut usia lebih tertarik pada aktivitas yang berhubungan dengan sosial keagamaan. Agama dapat

\footnotetext{
59 Zakiyah and Ibnu Hasan, "Studi Religiusitas Lansia
} Terhadap Perilaku Keagamaan Pada Lansia Perumahan memenuhi kebutuhan psikologis yang penting pada lansia untuk menghadapi kematian, menemukan dan mempertahankan perasaan berharga dalam kehidupan serta dapat menerima kekurangan di masa tua. ${ }^{59}$ Kondisi tersebut menjelaskan alasan jemaah membutuhkan mengikuti kajian dakwah sebagai pemenuhan kebutuhan sosial keagamaan.

Untuk faktor pekerjaan, jemaah terdiri dari beragam kalangan pekerjaan dan tidak spesifik jenis pekerjaan yang mereka miliki berpengaruh terhadap respons terhadap kajian. Adanya realitas respons terhadap jadwal kajian MDW pada hari minggu disayangkan oleh sebagian jemaah, karena mereka terkendala urusan pekerjaan menunjukkan adanya pengaruh faktor pekerjaan yang dihubungkan dengan atribut waktu penyelenggaraan kajian. Faktor situasi ekonomi atau pendapatan juga tidak ditemukan data bahwa hal tersebut berpengaruh terhadap respons jemaah MDW, karena pelaksanaan pengajian ini tidak dipungut biaya. Faktor pribadi lainnya adalah faktor gaya hidup yang tercermin dalam aktivitas keseharian, minat dan opini dari konsumen. Hasil temuan data menunjukkan adanya pengaruh gaya hidup jemaah yang terbiasa menghadiri kajian dakwah selain kegiatan dakwah MDW. Kebiasaan menghadiri kajian, membuat mereka lebih mudah tertarik dan merespons secara positif terhadap produk kajian dakwah. Di lain sisi, kebiasaan mereka dalam komunitas pengajian membentuk interaksi pertemanan yang kuat antar sesama jemaah, sehingga hal ini memicu pemenuhan kebutuhan bersosialisasi di kalangan jemaah MDW. Jemaah

Tegal Sari Ledug Kembaran Banyumas," Islamadina 15, no. 2 (2015): 3-4, doi:10.30595/islamadina.v0i0.1656. 
menyarankan pengurus untuk membentuk seragam pengajian sebagai bentuk identitas kegiatan pengajian MDW, menyukai aktivitas wisata kuliner bersama jemaah lainnya seusai kajian MDW, serta adanya saran pengadaan wisata religi oleh salah satu jamaah merupakan bukti adanya pengaruh faktor pribadi, spesifiknya pada minat dan opini jemaah.

Faktor psikologis terdiri dari faktor motivasi, persepsi, proses belajar, kepercayaan dan sikap. Faktor motivasi yang berpengaruh pada konteks jemaah MDW adalah motivasi spiritual, motivasi pemenuhan kebutuhan rohani (keagamaan) dan ketenangan karena merasa dekat dengan Allah Swt. Berikutnya, motivasi yang dimiliki oleh jemaah MDW terhadap kajian dakwahnya adalah motivasi sosial atau bersosialisasi dengan semakin banyak orang (jemaah) lainnya. Motivasi sosial pada konteks ini adalah kecenderungan membutuhkan ukhuwah islamiah. Untuk faktor persepsi yang berpengaruh dalam merespons kajian MDW adalah persepsi terhadap dai atau pemateri. Jemaah mempersepsi dai memiliki kemampuan baik dalam menyampaikan dakwah. Sehingga jemaah akan antusias mengikuti dai yang menyampaikan materinya. Persepsi ini semakin menguat karena jemaah memiliki pengalaman positif kepada dai tersebut. Dai yang rutin menjadi pemateri kajian Majelis Dzikir Walisongo juga merupakan dai yang mengisi kajian dakwah di beberapa tempat termasuk salah satunya di Majelis Dzikir Walisongo. Sebagian jemaah telah mengenal bagaimana kualitas dakwah yang disampaikan oleh dai, sehingga hal ini merupakan indikator adanya pengaruh faktor proses belajar atau pengalaman jemaah sebagai konsumen terhadap atribut produk dai. Kepercayaan memiliki arti deskripsi keyakinan dan sikap konsumen terhadap sesuatu. Jika dihubungkan dengan realitas jemaah MDW, terdapat kepercayaan dan sikap positif terhadap kegiatan ibadah salah satunya adalah, bahwa mengikuti pengajian tersebut dapat bernilai ibadah dan mendatangkan pahala. Kegiatan pengajian mampu mengingatkan dan mengondisikan diri jemaah kepada nilai-nilai tauhid. Mereka juga memiliki sikap-sikap memprioritaskan kegiatan berorientasi akhirat dibanding dengan duniawi, seperti pada konteks tetap mengupayakan hadir pada kegiatan pengajian meskipun harus merelakan urusan pekerjaan. Hal tersebut, mempengaruhi keputusan mereka menyukai ikut kegiatan pengajian termasuk pengajian Majelis Dzikir Walisongo.

\section{Kesimpulan}

Jemaah Majelis Dzikir Walisongo (MDW) merespons positif adanya kegiatan dakwah atau pengajian karena mereka memiliki gaya hidup yang agamis atau religius. Karakter paham keagamaan mereka tentu mengikuti organisasi penyelenggara kajian dakwah yang mereka ikuti yakni berpaham ahlusunah waljamaah atau kultural moderat. Setiap kegiatan keagamaan yang diikuti dimotivasi oleh keinginan mendapatkan pemenuhan kebutuhan spiritual. Bentuk kebutuhan spiritual yang dimaksud sebagaimana spiritualisme masyarakat urban atau konsep urban sufisme yang telah banyak dibahas pada studi terdahulu. Urban sufisme sendiri merupakan konsep ibadah dan keagamaan yang lazim ditemukan pada masyarakat muslim perkotaan. Mereka (jemaah) bahkan memandang pemenuhan kebutuhan spiritualitas lebih utama 
dibanding mendapatkan pengetahuan atau wawasan baru dari materi tausiah yang disampaikan dalam kajian. Selain pemenuhan kebutuhan spiritual, jemaah membutuhkan kajian dakwah karena dapat memberikan ruang untuk bersosialisasi dengan sesama jemaah pengajian. Kebutuhan sosial ini juga didukung dengan nilai-nilai ukhuwah islamiah yang dimiliki oleh jemaah sebagai anggota jamiah NU. Adanya kebutuhan ini memberikan wacana baru bahwa masyarakat muslim urban yang mengalami alienasi, karena kemajuan zaman tidak selalu hanya melakukan praktik ibadah sufistik yang bersifat individual seperti, zikir melainkan melakukan kegiatan yang bersifat sosial. Pada konteks jemaah MDW dengan membangun ikatan ukhuwah islamiah sesama anggota jemaah.

Pemasar tidak benar-benar memahami bagaimana perilaku pasarnya jika tidak menggali sampai menemukan faktor pembentuknya. Faktor yang mempengaruhi respons jemaah terhadap kegiatan pengajian MDW tergolong beragam terdiri dari faktor internal dan eksternal. Faktor eksternal meliputi budaya yakni nilai-nilai yang berkembang pada masyarakat muslim perkotaan seperti perilaku keagamaan cenderung berkarakter urban sufisme. Bentuk pemenuhan kebutuhan spiritualnya di pengaruhi oleh nilai sub budaya Nahdlatul Ulama dengan bentuk amal ibadah melakukan zikir dan istigasah. Faktor kelompok sosial yang memberikan pengaruh pada respons jemaah adalah rekomendasi rekan seprofesi, teman pengajian jemaah dan kelompok jamiah NU. Faktor rekomendasi keluarga memungkinkan berpengaruh, karena adanya jemaah yang satu anggota keluarga.

Faktor internal yang mempengaruhi antara lain faktor usia lanjut yang lebih termotivasi untuk terlibat dalam aktivitas sosial keagamaan, faktor motivasi spiritual dan motivasi sosial (bersosialisasi), faktor gaya hidup sering ikut kegiatan pengajian. Adapun faktor psikologis yang berpengaruh pada jemaah MDW adalah faktor motivasi spiritual dan motivasi sosial. Faktor persepsi terhadap dai berkualitas dikuatkan oleh pengaruh faktor pengalaman pernah menikmati langsung kualitas dari dai MDW saat ceramah di kajian lain menghasilkan respons positif jemaah terhadap dai kajian MDW. Jemaah MDW juga memiliki nilai atau kepercayaan bahwa mengikuti kajian dakwah termasuk beribadah dan akan mendapatkan pahala. Nilai tersebut sejalan dengan sikap jemaah yakni, mendahulukan kepentingan akhirat daripada duniawi, sehingga jemaah cenderung memprioritaskan waktu untuk menghadiri majelis dakwah dibandingkan kegiatan lainnya.

Bagi lembaga dakwah yang menjadikan masyarakat muslim perkotaan sebagai mitra dakwahnya dapat menjadikan temuan studi ini, sebagai referensi memahami perilaku pasar untuk menetapkan strategi dakwah yang sesuai. Bagi studi lanjutan, diharapkan memperdalam temuan bentuk praktik keagamaan masyarakat muslim perkotaan (urban muslim) dalam memenuhi kebutuhan spiritual dan kebutuhan lainnya tidak berhenti pada praktik sufisme saja. 


\section{Bibliografi}

Ali, Hasanuddin, and Lilik Purwandi. "Indonesia Middle Class Moslem: Religiosity and Consumerism." Jakarta, February 2017. https://alvara-strategic.com/whitepaperindonesia-middle-class-muslim-religiosity-and-consumerism/.

- - . "Indonesia Muslim Report 2019." Jakarta, December 2019. https://alvarastrategic.com/indonesia-muslim-report-2019/.

Ali, Hasanuddin, Lilik Purwandi, and Moh. Firmansyah. "The Potraits Of Urban Moslem Indonesia." Jakarta, July 2015.

https://www.researchgate.net/publication/314448949_The_Potraits_Of_Urban_Moslem Indonesia.

Andarwati, Lilis. "Sufisme Perkotaan Dan Pedesaan Di Era Modernisasi Dan Sekularisasi." Universum 10, no. 1 (2016): 41-48. doi:10.30762/universum.v10i1.222.

Anis, Muhammad. "Spiritualitas Di Tengah Modernitas Perkotaan." Jurnal Bayan II, no. 4 (2013): 1-15. http://s3ppi.umy.ac.id/wpcontent/uploads/2017/04/Spiritualitas_di_Tengah_Modernitas_Perko.pdf.

Bukhari. "Penerimaan Dan Penolakan Pesan Dakwah Dalam Interaksi Simbolik Da 'I Dan Mad' U." Miqot 39, no. 2 (2015): 377-89. doi:http://dx.doi.org/10.30821/miqot.v39i2.31.

Fazry, Rachma Waty. "Implementasi Kebijakan Ketahanan Pangan Di Kecamatan Cibogo Kabupaten Subang." Dinamika: Jurnal IImiah Ilmu Administrasi Negara 6, no. 4 (2019): 358-75. https://jurnal.unigal.ac.id/index.php/dinamika/article/download/3104/pdf.

Firmansyah, Anang. Perilaku Konsumen (Sikap Dan Pemasaran). Yogyakarta: Deepublish, 2018. Irhamdi, Muhamad. "Keberagaman Mad'u Sebagai Objek Kajian Manajemen Dakwah: Analisa Dalam Menentukan Metode, Strategi, Dan Efek Dakwah." Jurnal MD 5, no. 1 (2019): 5571. doi:https://doi.org/10.14421/jmd.2019.51-04.

Jati, Wasisto Raharjo. "Sufisme Urban Di Perkotaan: Konstruksi Keimanan Baru Kelas Menengah Muslim." Jurnal Kajian \& Pengembangan Manajemen Dakwah 05, no. 2 (2015): 175-99.

Kotler, Philip, and Kevin Lane Keller. Manajemen Pemasaran. Edited by Benyamin Molan. 2nd ed. Jakarta: Erlangga, 2012.

Ma'shum, Ishomuddin. "Siapa Penyusun Bacaan Istighotsah?" NU Online, 2013. https://www.nu.or.id/post/read/47541/siapa-penyusun-bacaan-istighotsah.

Mindari, Ellisyah. "Analisis Faktor-Faktor Yang Mempengaruhi Perilaku Konsumen Dalam Pengambilan Keputusan Pembelian Produk Roti Isi Krim Durian Di Desa Rantau Sialang Kecamatan Sungai Keruh." Jurnal Ekonomika XI, no. 2 (2020): 46-61. http://jurnal.borneo.ac.id/index.php/ekonomika/article/view/1437/966.

Muhadi, Ujang. "Membangun Efektifitas Dakwah Dengan Memahami Psikologi Madu" 4, no. 1 (2019). doi:10.29240/jdk.v4i2.1251.

Sari, D. K., Gunawan, D. \& Septiani, R. P. “Gambaran Coping Stress Pada Pendatang Baru Yang Tinggal Di Lingkungan Padat Dan Bising Di Jakarta." Psikoislamedia Jurnal Psikologi 3, no. 2548-4044 (2018): 125-36. doi:http://dx.doi.org/10.22373/psikoislamedia.v3i2.5619.

Syarif, Nasrul. "Marketing Dakwah." An-Nida" : Jurnal Prodi Komunikasi Penyiaran Islam 6, no. 1 (2017): 101-18. https://e-jurnal.stail.ac.id/index.php/annida/article/view/73. 
Wahyudi, Dedi, and Sri Prawita. "Faktor-Faktor Yang Mempengaruhi Perilaku Konsumen Dalam Memilih Sepeda Motor Harley Davidson." Jurnal Ilman: Jurnal Ilmu Manajemen 1, no. 1 (2014): 83-92. doi:http://dx.doi.org/10.35126/ilman.v1i1.55.

Yulianto, Hendra Bagus. "Manajemen Pemasaran Agama : Studi Tentang Strategi Dakwah Pengajian Bunda Muslimah Az-Zahra Sidoarjo." UIN Sunan Ampel Surabaya, 2017. http://digilib.uinsby.ac.id/19408/.

Zakiyah, and Ibnu Hasan. "Studi Religiusitas Lansia Terhadap Perilaku Keagamaan Pada Lansia Perumahan Tegal Sari Ledug Kembaran Banyumas." Islamadina 15, no. 2 (2015): 1-16. doi:10.30595/islamadina.v0i0.1656. 